\title{
John RYDER, The Things on Heaven and Earth
}

New York, Fordham University Press, 2013

\section{Alicia Garcia Ruiz}

\section{(2) OpenEdition \\ 1 Journals}

Electronic version

URL: http://journals.openedition.org/ejpap/523

DOI: 10.4000/ejpap.523

ISSN: 2036-4091

\section{Publisher}

Associazione Pragma

\section{Electronic reference}

Alicia Garcia Ruiz, « John RYDER, The Things on Heaven and Earth », European Journal of Pragmatism and American Philosophy [Online], VI-1 | 2014, Online since 08 July 2014, connection on 24 September 2020. URL : http://journals.openedition.org/ejpap/523 ; DOI : https://doi.org/10.4000/ejpap.523

This text was automatically generated on 24 September 2020

\section{(c) $\Theta \Theta \Theta$}

Author retains copyright and grants the European Journal of Pragmatism and American Philosophy right of first publication with the work simultaneously licensed under a Creative Commons AttributionNonCommercial-NoDerivatives 4.0 International License. 


\title{
John RYDER, The Things on Heaven and Earth
}

New York, Fordham University Press, 2013

\author{
Alicia Garcia Ruiz
}

\section{REFERENCES}

John Ryder, The Things on Heaven and Earth, New York, Fordham University Press, 2013.

\section{On Philosophical Education}

1 To many philosophical sensibilities the expression "Pragmatic Naturalism" may sound like a sort of oxymoron. We have a good news: it is not. John Ryder's new book The Things on Heaven and Earth will not persuade perhaps the most reluctant partisans of both sides, but it certainly shows how "pragmatic naturalism" is not necessarily a contradictio in adjecto, but rather an exciting theoretical approach. After reading this book, one acquires the confidence that pragmatic naturalism can be a valuable tool to deal satisfactorily with a good number of issues debated in virtually all fields of contemporary philosophy. This remarkable defense of pragmatic naturalism is also an instance of the best pragmatic legacy in terms of methodological fluidity and theoretical openness while using a convincing and clear style of argumentation.

Ryder's approach to pragmatic naturalism is not an unspecified appeal to methodological plurality. On the contrary, he shows that different disciplinary approaches to any subject-matter produce "virtuous circularities." According to Ryder, these circularities have the merit of allowing for a sound critique of many of the habitual, academic prejudices. Many times these academic prejudices unnaturally force students to choose between apparently opposing teams. This book should be received as a healthy invitation to cultivate a different attitude. Ryder successfully demonstrates 
how an encompassing approach can be well structured, clear and productive at once. In sum, this book should be carefully read in many introductory philosophy courses.

However, The Things on Heaven and Earth also has further merits. John Ryder is determined to demonstrate the plausibility and usefulness of combining pragmatism and naturalism. Despite the book deals with a considerable number of topics, its very precise structure covers a wide range of interests in an accessible and effective way.

In Part I, Ryder articulates the fundamental tenets of his proposal, as he provides a general framework to stress the contrasts and connections between the naturalist and the pragmatist perspective, along with a clear elucidation of the current debates on this issue. Part II develops the ontological and epistemological consequences of pragmatic naturalism, dealing with different areas of experience such as scientific research, religious views, and artistic practices. Finally, Part III accounts for the social and political relevance of his proposal. In particular, Ryder focuses his attention on the problems of contemporary democracies and international relations, while showing in what way pragmatic naturalism can be a helpful instrument to inform contemporary cosmopolitism.

5 The purpose that pervades this work is outspoken by the initial quote, the moment when Hamlet admonishes Horatio's "epistemic dogmatism:" "There are more things on heaven and earth, Horatio, than are dreamt of in your philosophy." The question will be to decide whether the genuine "naturalist" is Horatio or Hamlet. Following the lines of the traditional pragmatist attempt to elucidate practical contexts of knowledge, Ryder rightly affirms that the ultimate philosophical endeavor is to address the actual complexity of human experience. To pay due account to all the "things on heaven and earth" means here to study those regions of experience neglected during the 20th century, as the result of a reductive materialist interpretation of the concept of "nature." Although Ryder does not refer explicitly to a phenomenological conception of "nature," it is worth mentioning how his themes and perspectives keep a familiar resemblance with both Husserl's research on "regional ontologies" and with the phenomenological dispute on reduced conceptions of naturalism. ${ }^{1}$ In any case, pragmatic naturalism is intended to fill the void left by artificial, clear-cut divisions of experience as sketched in radical materialist interpretations of experience and nature.

6 Notwithstanding its high scope and its breadth of interests, The Things on Heaven and Earth does not fall into a flabby pluralism but provides a solid outlook where "the point is not to talk about everything but to articulate a philosophic perspective through which it is possible to make sense of whatever experience and thought reveal or generate, however they reveal or generate it" (9). With this aim in view, Ryder consistently claims for a rebuttal of two common epistemological assumptions with regard to metaphysical issues. In the first place, he affirms that conceptualizing the "existence" problem in terms of deciding that 'this' or 'that' "exists" is unnecessarily reductive and insufficient to cope with the complexity of human experiences. Secondly, Ryder suggests that the ambition of making a sort of "reality list" in a Quinean style eventually entails more epistemological problems than it solves. Thus, the book proposes a totally different task for epistemology, i.e. the exploration of the variety of conditions under which our very frames of understanding are constructed.

7 Therefore, Ryder's approach is not to regard metaphysical issues as misleading philosophical problems and, consequently, to discard them. On the contrary, problems that stem from these metaphysical issues should be confronted through an extensive 
understanding of epistemology, specifically connected to ontological inquiry. This would allow for a satisfactory elucidation of the meaning of existential propositions: "The metaphysical - or, better, the ontological - question is not whether this or that exists but rather how we might understand whatever it is what exist" (1). In this sense, a distinctive trait of pragmatic naturalism would be a certain "ontological tolerance" towards the vast domain of the real that would make possible to identify a good number of candidates as suitable "sources of knowledge," in contrast to the prejudicial attitudes displayed by other understandings of ontology. However, Ryder rightly specifies that his ontological tolerance does not equate to a rejection of naturalism. The challenge is to construct a solid bridge between pragmatism and naturalism that can provide a more encompassing approach to the varieties of human experience.

\section{A Pragmatic Naturalist Point of View}

8 This book undertakes a reconciliation of pragmatism and naturalism on the basis of their respective accounts of the concepts of "experience" and "nature." As Ryder observes, "in a nutshell, for pragmatism nature is understood in terms of experience, and for naturalism experience is understood in terms of nature" (22). In order to prove how both views can come together, Ryder settles a preliminary framework for pragmatic naturalism by clarifying three main tenets. First, he explains how the conceptual struggle between objectivism and constructivism can be avoided through the recognition that both perspectives can be justified without the need of a mutual exclusion. Interestingly, Ryder relocates this debate along the lines of the split between modernism and postmodernism. Ryder's account of this debate is summarized in four plain and precise propositions: 1) Natural Phenomena have objective, determinate traits; 2) the traits of natural phenomena are knowable; 3) the process of inquiry is necessarily conditioned and perspectival; and 4) human interaction with the rest of nature, cognitive or otherwise, is active and creative. According to Ryder, points 1 and 2 would define the modern perspective while points 3 and 4 correspond to the postmodern view. In order to connect these contending positions, the author exposes a painstaking and convincing argumentation on how the four propositions are simultaneously true, which is possible when we endorse a relational perspective on nature.

9 Second, Ryder reinterprets Dewey's relational ontology by complementing it with the ordinal naturalism of Justus Buchler. This combination is found at its best in the theoretical work of the so-called Columbia School. The recovery of this pragmatist legacy is one of the most appealing achievements of the book. The author suggests that the original, naturalist trait of pragmatism can be re-appropriated in order to overcome the prevalence of Rortyan extreme relativism and rejection of objectivism. ${ }^{2}$ The basic ontological idea underlying this stress on relationality is that "all 'things' are constituted by constituents and their relations, and that no constituent is atomic" (41). In other words, nature as we experience it is not divided into simple pieces of information or empiria in the materialist sense; on the contrary, nature is absolutely relational. Interestingly, Ryder remarks that absolute relationality does not mean to assume the necessity of an Absolute since this would be to claim for non-relational entities. For this reason, even though relational ontology of "constitutive relations" opposes to reductive materialism, it needs not to be a form of idealism either. 

insist that any one way at it has a monopoly on access" (8). and other contexts" (43).

\section{The Practical Value of Philosophy} experienced. relations existing among constituents of this diversity.

Third, we find that pragmatic naturalism constitutes a rebuttal of the hegemony of deductive argumentation in contemporary philosophy. Mathematical language is just but one form of reasonable activity among others. If pragmatic naturalism possesses its own specificity in relation to pragmatism, then there is no point in prescribing only one mode of valid argumentation: "Nature is complex, and there is no good reason to

The reader is led to see the remarkable and coherent versatility of this perspective, in relation to a considerable variety of philosophical subjects, through the defining features of pragmatic naturalism as stated by Ryder. In short, the analytic potential of pragmatic naturalism can be described in the following way: "pragmatic naturalism is a relational philosophy; it is a philosophy for which nature is a category sufficient for all things; it holds that nature consists of more than material objects; it proceeds as if natural science is one of several sources of knowledge; and it is a philosophical perspective that expects to be evaluated by its usefulness and value in philosophical

The third part of The Things on Heaven and Earth focuses on the practical value of philosophy. If the value of ideas is to be found in the function they accomplish, as Ryder affirms, they can be therefore evaluated in light of how many philosophical deadlocks they help to avoid and in the number of regions of experience that they help to elucidate. The list of virtues of pragmatic naturalism singled out by Ryder simultaneously represents a declaration of purposes and an assortment of criteria for judging the success of his proposal as a whole. First, pragmatic naturalism rejects to support philosophical dualisms - mind and body, self and world, objectivity and subjectivity, etc. - in a way that each one becomes a problem for the other. Each counterpart makes a compelling claim that calls our attention, so it is artificial and unfruitful to tear apart in clashing theoretical pieces a world that is in fact coherently

3 Second, pragmatic naturalism can be considered as the contemporary expression of a tradition that stays away from reductionism in the above mentioned sense. The pragmatic naturalist perspective allows us to accept the multiplicity of nature without dissolving some of its features. The relational understanding allows us to recognize and to acknowledge the diversity in nature while at the same time accounting for specific

14 Third, pragmatic naturalism permits to recover the dimension of objectivity in experience, which has been greatly neglected in the postmodern trends of contemporary pragmatism. This move makes it possible to connect perspectivism and objectivity in a satisfactory way. As Ryder points out, the absence of absolute knowledge does not preclude objectivity, either epistemological or ontological. Perspectival epistemology and objectivist ontology are not mutually exclusive.

A fourth virtue, Ryder affirms, shows how a non-dogmatic interpretation of the idea of "nature" permits to regard multiple dimensions of our experience (art, music, poetry, etc.) as cognitively significant activities. None of these insights are produced by science but they constitute judgments that make available to us important traits of the world. 

"logical" shift of much of historical and contemporary philosophy. Deductive reasoning is not the only valid form of evaluating an idea or proposition. Though pragmatic naturalism is not antifoundationalism, it does not pretend to provide the world with unshakable foundations.

, pragmatic naturalism constitutes a good resource to deactivate dogmatic positions in the social-political realm. A "pragmatic ethos," ${ }^{3}$ which is essentially an assortment of practices and attitudes like experimentalism, self-correction, and fallibilism, can be productively interpreted along democratic lines. After reading the last part of the book, one gets the vivid impression that pragmatic naturalism really opens the path for an interesting set of political applications, in line with Dewey's perspective on democracy as an intelligent and creative activity. A wise use of indeterminacy and fluidity, as depicted by Ryder, allows the cultivation of common interests between individuals and communities with different backgrounds, which is an appropriate challenge to the current state of affairs of global international relations.

In sum, the contemporary increasing interest ${ }^{4}$ in pragmatic naturalism and the acuteness of the arguments exposed by Ryder reveal The Things on Heaven and Earth as a timely and constructive contribution to the field. However, not only academic debates or scholarly contentions are addressed here. The book also exhibits a fruitful effort to connect philosophy and life. Ryder's pursuit of commonalities is perhaps one of the most attractive points of the book, insofar as it is symptomatic of an ethical shift that pervades our current societies. The need for neutralizing the adverse effects of centuries of individualism is paving the way for a reappraisal of the meaning we give to the fact (and challenges) of living together. Philosophy can provide valuable instruments of rationality for these new horizons and this book is a good proof of it.

\section{NOTES}

1. See Husserl E., (1952), Ideen I, Hua. IV, Den Haag, ed. Marly Biemel, § 149, and Rosenthal S. B., Bourgeois P. L., (1980), Pragmatism and Phenomenology, Amsterdam, John Benjamins Publishing.

2. Along the same lines, see Bernstein R., (1983), Beyond Objectivism and Relativism, Philadelphia, University of Pennsylvania Press.

3. For the idea of a "Pragmatic Ethos" see Bernstein R., (1991), The New Constellation: The EthicalPolitical Horizons of Modernity/Postmodernity, New York, Polity Press, p. 324.

4. See Shook J., (2003), Pragmatic Naturalism and Realism, Armherst, N.Y, Prometheus Books. 


\section{AUTHORS}

ALICIA GARCIA RUIZ

University of Barcelona, Spain

aliciagarciaruiz[at]gmail.com 